http://www.jfas.info

\title{
ARTOCARPUS ALTILIS COMPOUND BASED STUDY FOR ANTI-CANCER PROLIFERATION ON HELA CELL VIA ELECTROPORATION METHOD
}

\author{
S. Ganeson ${ }^{1}$, M. M. A. Jamil ${ }^{1, *}$, M. N. Adon ${ }^{1}$, R. A. Wahab ${ }^{2}$ and M. S. Ahmad ${ }^{1}$ \\ ${ }^{1}$ Biomedical Modelling and Simulation (BIOMEMS) Research Group, Faculty of Electric and \\ Electronic Engineering, Universiti Tun Hussein Onn Malaysia, 86400 Batu Pahat, Johor, \\ Malaysia \\ ${ }^{2}$ Department of Biomedical Science, Kulliyah of Allied Health Sciences, International Islamic \\ University Malaysia, 25200 Kuantan, Pahang, Malaysia
}

Published online: 05 October 2017

\begin{abstract}
Survivors of cancer often have multiple permanent side effects due to the usage of drugs during the therapy. This study combining the compound artocarpus altilis and the optimized electroporation method for maximum HeLa cancer cell anti-proliferation activity. Artocarpus altilis or also known as sukun, is a natural compound, which has the capability to treat cancer as it has anti-proliferation effect in cancerous cells. Hence, in this current work, voltage amplitude of $200 \mathrm{~V} / \mathrm{cm}, 400 \mathrm{~V} / \mathrm{cm}, 600 \mathrm{~V} / \mathrm{cm}, 800 \mathrm{~V} / \mathrm{cm}, 100 \mathrm{~V} / \mathrm{cm}$ with $30 \mu \mathrm{s}$ of pulse duration used in electroporating HeLa cancer cell to look at the effects on cell's extension, cell size and growth rate. However, this study requires further investigation to identify the optimal electroporation conditions that can be applied to effectively deliver the artocarpus altilis extracts to the HeLa cancer cells in order to inhibit its proliferation.
\end{abstract}

Keywords: electroporation; irreversible electroporation; artocarpus altilis.

Author Correspondence, e-mail: mahadi@uthm.edu.my

doi: http://dx.doi.org/10.4314/jfas.v9i4s.18 


\section{INTRODUCTION}

This review elucidates technique of Irreversible Electroporation with the combination of Sukun (Artocarpus Altilis) extract on HeLa cancer cell anti-proliferation activity. Electroporation or also known as electropermeabilization is a process where cells are exposed to an electric field to form nanoscale pores through a cell membrane [1-2]. This process is used to deliver impermeable particles into cells such as genes (DNA) and drugs [3-4]. Electroporation technique can be applied to almost all types of cells that cannot be accessible through other methods. Electroporation is a process where structural rearrangement done within the cell membrane by using short intense electric pulse [5-6]. Permanent or temporary pores in the cell membrane is depending on the voltage parameter applied to the cell. Irreversible Electroporation happens when electric field causes permanent pores of the membrane, while Reversible Electroporation is the temporary permeabilization of cell membrane after which the cells sustained [7-8]. Previous study has proven that Sukun extract has the ability to decrease the cancer cell viability and has potential as an anti-cancer agent. This is because of its contain called artocarpin which reduced cell viability by inducing apoptosis [9]. Since the natural properties of the Artocarpus Altilis inhibit the proliferation of cancer cells, electroporation can be applied to deliver this plant extracts to the cells, thereby opposing the proliferation of the HeLa cancer cells. Thus, research on this Electroporation blending of Natural extract must be a vital improvement of biomedical application. By date, there is no research by combining this method.

\subsection{Electroporation}

Numerous studies have proved that proper electric pulse could permeabilize cell membrane and it is thought to produce aqueous-filled pores [11-12]. Electroporation is an extensively known technique to deliver impermeable particles to the cell, like drugs, antibodies and deoxyribonucleic acid [13-14]. According to [21], electroporation is effective with nearly all cell and species types which shows its versatility. Electroporation is also recognized as a nontoxic and non-viral method. Moreover, EP process does not modify the function and biological morphology of focused cell, safer, less immunologic and highly efficient. Electroporation is a phenomenon to generate permeabilization of cell membrane in both 
reversible (RE) mode and cell irreversible (IRE) mode. Electrogenetheraphy; method for gene insertion into cells (15-16) and Electrochemotherapy; uptake of potent and non-permeable anti-cancer drugs to kill cancerous cells (17-18) are the important application of reversible electroporation at present. Irreversible electroporation however has been investigated comprehensively in cell engineering. Previous research on liver cancer study has proven that IRE has the ability to kill the cancerous cells completely in non-thermal system (19-20). IRE is not only being practiced in medical field, however it is also being used in food industry for sterilization purpose and food pre-processing since 1961 [8].

\subsection{Artocarpus Altilis Extract}

To date, there are plenty of researches focusing on the findings of new types of natural chemotherapeutic agents derived from plants. This is proved to be excellent sources of new compounds. Herbal medicines have been used in medication over the past decade. Approximately $75 \%$ of the world's population has therapeutic experience over herbal remedies according to World Health Organization. Artocarpus Altilis is one of the plants that have potential in curing cancer. Artocarpus Altilis is a member of the genus Moraceae that contains about 50 species of trees. It is widely used in traditional medication to heal inflammation, infection, diabetes, cardiovascular problems and so on. It is proven by Enos Tangke Arung that Sukun wood extract has the capability to treat cancer. Human breast cells viability decreases after being induced with Sukun extract, which primarily contains artocarpin [9-10].

\section{METHODOLOGY}

\subsection{Cell Lines and Culture}

In this research, experiments are conducted entirely using HeLa cancer cell. HeLa cell cultured in $25 \mathrm{~cm}^{2}$ flask kept in $\mathrm{CO}_{2}$ incubator. Several aspects must take into consideration such as accurate temperature control, humidity, $\mathrm{CO}_{2}$, reliability and sterility. Firstly, old culture media aspirated from the cell culture flask will be transferred into conical flask. Cells are washed by using $3 \mathrm{ml}$ of PBS. PBS will then be aspirated from the flask. Then, $2 \mathrm{ml}$ of trypsin added into the culture and culture flask is stored in $\mathrm{CO}_{2}$ incubator for 10 minutes. After 10 minutes of incubation, cells are observed under a microscope. Fully trypsinized cells 
should appear in rounded shape and no longer attached to the surface of the flask. $1 \mathrm{ml}$ of media will be added to the old culture flask and $5 \mathrm{ml}$ to the new flask. Next, about $0.2 \mathrm{ml}$ of cells are aspirated and dispensed into new flask and the availability of the cells in the new flask are examined. Then, HeLa cell will be stored in an incubator at $37^{\circ} \mathrm{C}$ and $5 \% \mathrm{CO}_{2}$ gas. Cells will undergo sub-culture process every 3 to 5 days whenever they meet $80 \%$ to $90 \%$ of confluency.

\subsection{Electroporation}

Electroporation setup is to extensively electroporate the cells, which means create pores that can be either temporary irreversible electroporation or reversible electroporation. Purpose of this technique is to deliver biological elements into cells for further live investigations. ECM830 electroporator was used for electroporating the cells in this experiment. There are two modes of operation in ECM830 electroporator, $5 \mathrm{~V}$ to $500 \mathrm{~V}$ will be the low voltage mode and pulse length of $10 \mathrm{~ms}$ to $999 \mathrm{~ms}$. And high voltage mode with output voltage ranging from $501 \mathrm{~V}$ to $3 \mathrm{KV}$ and pulse duration of $10 \mu \mathrm{s}$ to $600 \mu \mathrm{s}$. Electroporation method comes with cuvette (BTX Harvard Apparatus) with electrode gaps of 1, 2 and 4mm and volume of $100 \mu 1$, $200 \mu \mathrm{l}, 400 \mu \mathrm{l}$ accordingly to the exposure of large suspension volumes. In this experiment, cuvette with $4 \mathrm{~mm}$ is used as it is suitable for mammalian cell. Cell must reach confluency approximately $80-90 \%$ on the day of electroporating the cell. Next, cells will be mixed with triple express and neutralized with same amount of volume of growth medium. Then, $800 \mu 1$ of cell transferred into a $4 \mathrm{~mm}$ electrode gap cuvette (BTX Harvard Apparatus). After that, cuvette placed into the safety stand. Once done, safety stand is connected to BTX 830 Electroporator. Finally, ECM 830 Electroporator is set up accordingly (parameter involved: voltage and pulse duration) and induced. The electroporated cells were then seeded into 6-wells plates containing $2 \mathrm{ml}$ of complete growth medium. At last, it is incubated at $37^{\circ} \mathrm{C}$ and $5 \%$ of $\mathrm{CO}_{2}$ prior to harvesting. 


\section{RESULTS AND DISCUSSION}

Table 1. Image of HeLa cell after electroporation in $25 \mathrm{~cm}^{2}$ flask (scale bar $50 \mu \mathrm{m}$ )

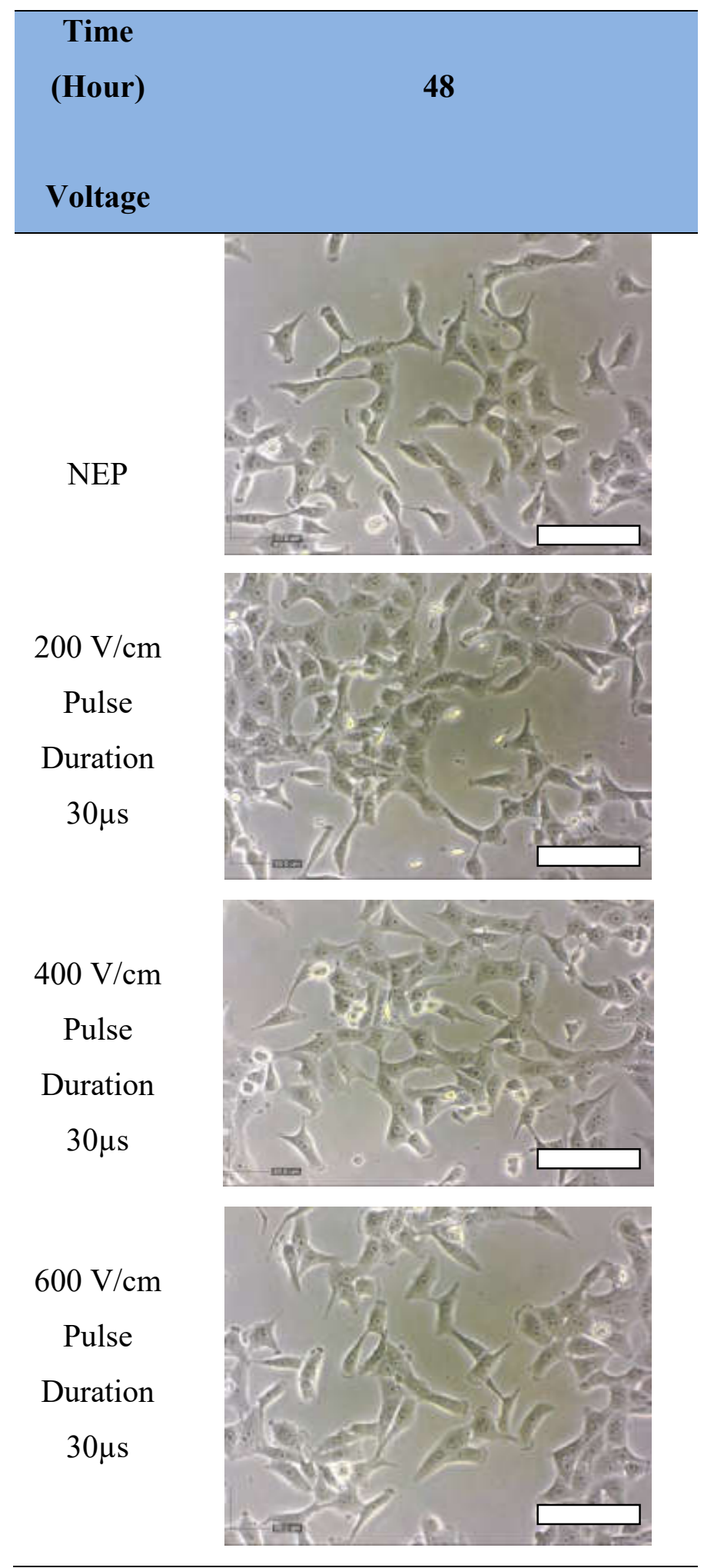




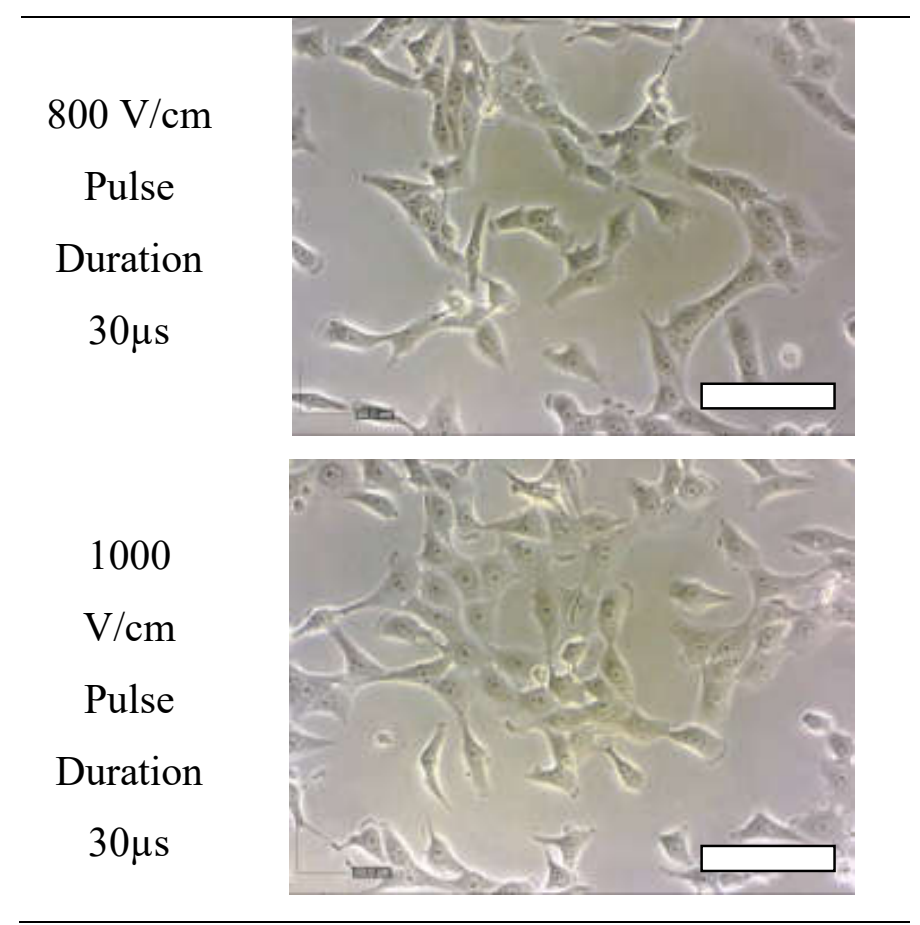

Table 2. Electroporated and non electroporated cell parameter

\begin{tabular}{cc}
\hline Voltage $(\mathbf{V} / \mathbf{c m})$ & Average Cell Length $(\boldsymbol{\mu m})$ \\
\hline NEP & 59.13 \\
200 & 59.38 \\
400 & 56.62 \\
600 & 53.13 \\
800 & 62.25 \\
1000 & 59
\end{tabular}

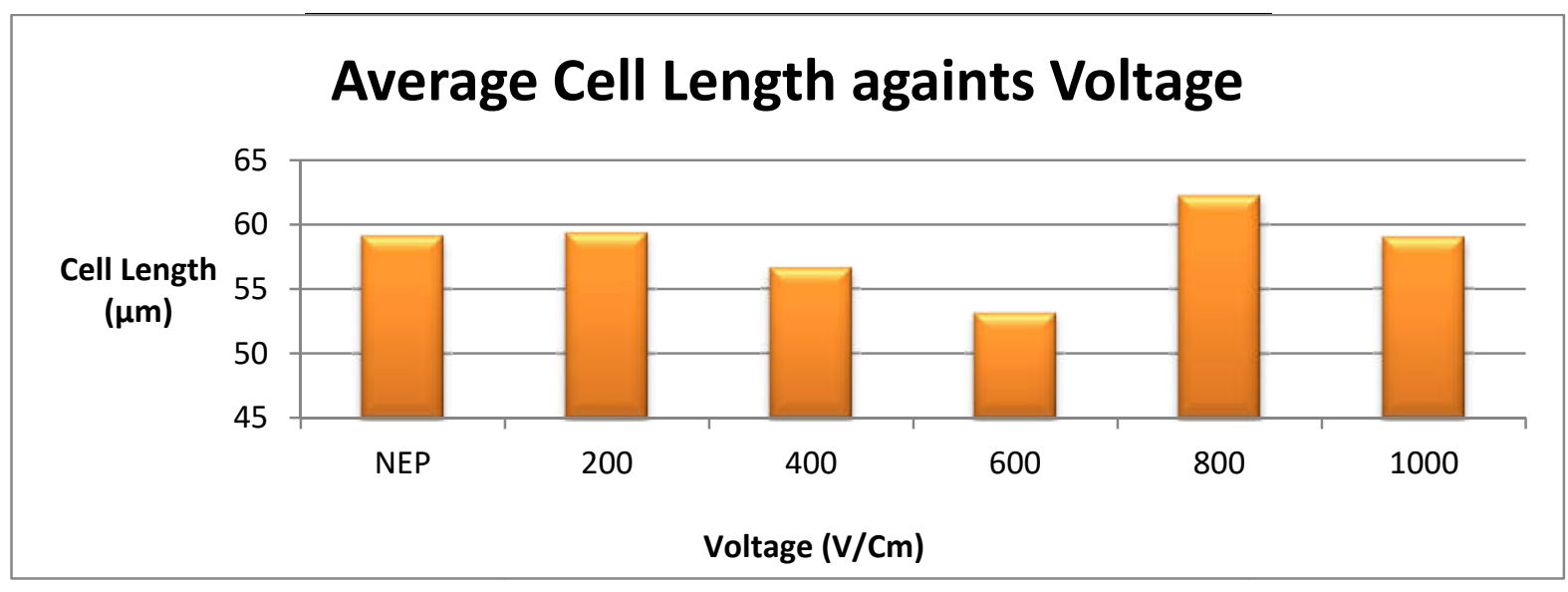

Fig.1. Average cell length $(\mu \mathrm{m})$ against voltage $(\mathrm{V} / \mathrm{cm})$

Referring to Table 1, the electric field application does not contribute much effects on the HeLa cell in the first $6^{\text {th }}$ hour. However, when compared to the control cell, the experimental 
data shows electric field does has effect on the growth of the cell after it has been incubated for 12 hours and more. The result shown in Table 2 shows the comparison of the HeLa cell length with electric pulse and without electric pulse. At the same time, electroporation also enhances the proliferation of HeLa cells. This is due to the significant increase in the electrical permeability when subjected to electroporation. Electroporation cause temporal membrane defects, where the electrical impedance of the plasma membrane began to fluctuate after the application of electroporation. As proven in the previous study, the use of electric field alters the permeabilization of a cell membrane in order to form nanoscale pores in the cell membrane. This leads to absorption of surrounded medium and nutrients and changes the size of the cell and proliferation of HeLa cell.

Fig. 1 shows the graph of the cell length average versus voltage (non-electroporation, 200v/ $\mathrm{cm}, 400 \mathrm{~V} / \mathrm{cm}, 600 \mathrm{~V} / \mathrm{cm}, 800 \mathrm{~V} / \mathrm{cm}$ and $1000 \mathrm{~V} / \mathrm{cm}$ ) with the pulse duration of $30 \mu \mathrm{s}$. The EP cell spread to a maximum length of $62.25 \mu \mathrm{m}$ with $800 \mathrm{~V} / \mathrm{cm}$ and minimum length of $53.13 \mu \mathrm{m}$ with $600 \mathrm{~V} / \mathrm{cm}$. Overall, the experiment demonstrated that various voltage parameters do effects on HeLa cell's extension, cell size and growth rate. However, this study requires further investigation to identify the optimal electroporation conditions that can be applied to effectively deliver the Artocarpus Altilis extracts to the HeLa cancer cells in order to inhibit its proliferation.

\section{CONCLUSION}

This proposed method of using electroporation with Sukun extract were experimented and discussed in detail. Investigation on both EP and Sukun extract proven that these methods can be combined in in-vivo studies to demonstrate the cell response towards the treatment. Currently, we are at the stage of establishing the Electroporation parameter. Next stage is to investigate on the compound extract (Artocarpus Altilis) and the anti-cancer mechanism by combining the compound Artocarpus Altilis and the optimized Eletroporation method for maximum HeLa cancer cell anti-proliferation activity. It is hoped that the result of this research will lead to the development of a better cancer treatment. 


\section{ACKNOWLEDGEMENTS}

The author would like to convey her appreciation to supervisor Associate Professor Dr. Muhammad Mahadi Abdul Jamil for the guidance support and acknowledge the financial support of Ministry of Education Malaysia through MyMasters (MyBrain15).

\section{REFERENCES}

[1] Chu G, Hayakawa H, Berg P. Electroporation for the efficient transfection of mammalian cells with DNA. Nucleic Acids Research, 1987, 15(3):1311-1326

[2] Lamichhane T N, Raiker R S, Jay S M. Exogenous DNA loading into extracellular vesicles via electroporation is size-dependent and enables limited gene delivery. Molecular Pharmaceutics, 2015, 12(10):3650-3657

[3] Gothelf A, Mir L M, Gehl J. Electrochemotherapy: Results of cancer treatment using enhanced delivery of bleomycin by electroporation. Cancer Treatment Reviews, 2003, 29(5):371-387

[4] Jiang C, Davalos R V, Bischof J C. A review of basic to clinical studies of irreversible electroporation therapy. IEEE Transactions on Biomedical Engineering, 2015, 62(1):4-20

[5] Weaver J C. Electroporation of cells and tissues. IEEE Transactions on Plasma Science, 2000, 28(1):24-33

[6] Santra T S, Tseng F G. Electroporation for single-cell analysis. In F. G. Tseng, \& T. Santra (eds), Essentials of single-cell analysis. Berlin: Springer, 2016, pp. 55-83

[7] Rubinsky B. Irreversible electroporation in medicine. Technology in Cancer Research and Treatment, 2007, 6(4):255-259

[8] Narayanan G. Irreversible electroporation. Seminars in Interventional Radiology, 2015, 32(4):349-355

[9] Arung E T, Wicaksono B D, Handoko Y A, Kusuma I W, Yulia D, Sandra F. Anti-cancer properties of diethylether extract of wood from sukun (Artocarpus altilis) in human breast cancer (T47D) cells. Tropical Journal of Pharmaceutical Research, 2009;8(4):317-324

[10] Mohanty M, Pradhan C. A review on phytochemistry, bio-efficacy, medicinal and ethno-pharmaceutical importance of Artocarpus altilis. International Journal of Pharmacy and Pharmaceutical Research, 2015, 3:219-231 
[11] Tarek M. Membrane electroporation: A molecular dynamics simulation. Biophysical Journal, 2005, 88(6):4045-4053

[12] Chopinet L, Rols M P. Nanosecond electric pulses: A mini-review of the present state of the art. Bioelectrochemistry, 2015, 103:2-6

[13] Davalos R V, Mir L M, Rubinsky B. Tissue ablation with irreversible electroporation. Annals of Biomedical Engineering, 2005, 33(2):223-231

[14] Neal R E, Garcia P A, Kavnoudias H, Rosenfeldt F, Mclean C A, Earl V, Bergman J, Davalos R V, Thomson K R. In vivo irreversible electroporation kidney ablation: experimentally correlated numerical models. IEEE Transactions on Biomedical Engineering, 2015, 62(2):561-569

[15] Gehl J. Electroporation: Theory and methods, perspectives for drug delivery, gene therapy and research. Acta Physiologica, 2003, 177(4):437-447

[16] Chang L, Li L, Shi J, Sheng Y, Lu W, Gallego-Perez D, Lee L J. Micro-/nanoscale electroporation. Lab on a Chip, 2016, 16(21):4047-4062

[17] Sersa G, Miklavcic D, Cemazar M, Rudolf Z, Pucihar G, Snoj M. Electrochemotherapy in treatment of tumours. European Journal of Surgical Oncology, 2008, 34(2):232-240

[18] Miklavcic D, Kotnik T. Electroporation for electrochemotherapy and gene therapy. In P.

J. Rosch, \& M. S. Markov (Eds.), Bioelectromagnetic medicine. New Jersey: Informa Healthcare, 2004, pp. 637-656

[19] Miller L, Leor J, Rubinsky B. Cancer cells ablation with irreversible electroporation. Technology in Cancer Research and Treatment, 2005, 4(6):699-705

[20] Davalos R V, Garcia P A, Rossmeisl J H, Robertson J L, Neal R E. Irreversible electroporation to treat aberrant cell masses. United States patent US 8,992,517, 2015

[21] Nickoloff J. A. Electroporation protocols for microorganisms. Berlin: Springer Science and Business Media, 1995.

\section{How to cite this article:}

Ganeson S, Jamil MMA, Adon MN, Wahab RA, Ahmad MS.Artocarpus altilis compound based study for anti-cancer proliferation on hela cell via electroporation method. J. Fundam. Appl. Sci., 2017, 9(4S), 310-318. 